\title{
KONTRIBUSI ISLAM TERHADAP AKUNTANSI
}

\author{
Ivo Sabrina*
}

\begin{abstract}
Contribution of Islam in Accounting. This study will focus on the comparison between the accounting and another definition to find the harmony and unity of meaning in it. This study uses the approach of the historical development and significance of accounting in Islam. in the perspective of the Quran and Hadith, the meaning of accounting is general and covers the whole of human activity in the lives interact and transact among others, both religious and related fields $m u$ 'âmalah areas and socioeconomic transac-tions in general.
\end{abstract}

Keywords: islam, transaction, accounting, mu'âmalah

Abstrak: Kontribusi Islam terhadap Akuntansi. penelitian ini akan membandingkan satu definisi akutansi dengan definisi yang lain untuk menemukan keselarasan dan kesatuan makna yang ada di dalamnya. Studi ini menggunakan pendekatan sejarah perkembangan dan makna akuntansi dalam Islam. Dalam perspektif Alquran dan Hadis, makna akutansi itu bersifat umum dan menyeluruh yang meliputi seluruh aktivitas manusia dalam kehidupan berinteraksi dan bertransaksi antar sesama, baik terkait bidang ibadah maupun bidang muamalah dan transaksi sosial ekonomi pada umumnya.

Kata Kunci: Islam, transaksi, akuntansi, muamalah

Naskah diterima: 4 Januari 2012, direvisi: 4 Juni 2012, disetujui: 10 Juni 2012.

* Sekolah Tinggi Ilmu Ekonomi Bisnis Indonesia (STIEBI). Jl. Kebayoran Lama 46, Jakarta, 11560. E-mail: ivosabrina@ymail.com 


\section{Pendahuluan}

Akuntansi merupakan salah satu ilmu yang bersifat praktis atau terapan yang pada saat sekarang ini dipakai di seluruh aktivitas kita. Dalam akuntansi terdapat prinsip, standar, asumsi, teknik, serta prosedur yang dijadikan landasan dalam pelaporan keuangan, berisi tentang informasi-informasi yang berguna dalam memantau aktivitas ekonomi dan memengaruhi pengambilan keputusan bagi para pemakainya.

Penerapan pengetahuan di bidang akuntansi ini tentu semakin luas dan kompleks jika dihadapkan pada bisnis dengan skala yang lebih besar. Seperti ilmu-ilmu lainnya, ilmu akuntansi juga berkembang sesuai perkembangan teknologi dan peradaban manusia. Selain itu, faktor kebutuhan juga ikut serta dalam perkembangan akuntansi itu sendiri. Akan tetapi, baik akuntansi maupun ilmuilmu lain tidak berkembang dengan sendirinya tanpa adanya hal yang cukup berarti yang dapat mendorong akuntansi tersebut berkembang dan bertahan hingga sekarang.

Sebagai sebuah cara hidup (way of life) yang serba cukup, Islam telah menyediakan tuntunan yang sangat gambling bagi manusia dalam menjalani kehidupan dalam semua aspeknya. Islam berorientasi pada tujuan (goal-oriented). Prinsip-prinsip yang mengarahkan pengorganisasian kegiatan-kegiatan ekonomi pada tingkat individu dan negara bertujuan untuk mencapai tujuan-tujuan menyeluruh dari sistem ekonomi Islam. Sebagai sebuah cara hidup (way of life) yang serba cukup, Islam telah menyediakan tuntunan yang sangat gamblang bagi manusia dalam menjalani kehidupan dalam semua aspeknya. Islam berorientasi pada tujuan (goal-oriented). Prinsip-prinsip yang mengarahkan pengorganisasian kegiatan-kegiatan ekonomi pada tingkat individu dan negara bertujuan untuk mencapai tujuan-tujuan menyeluruh dari sistem ekonomi Islam. ${ }^{1}$

Perdebatan mengenai definisi akuntansi telah dimulai sejak 1930 sampai 1970. Para akuntan memiliki pandangan yang berbeda-beda tentang proses akuntansi dalam menguraikan perbedaan teori-teori. Pandangan-pandangan tersebut di antaranya adalah akuntansi sebagai bahasa, akuntansi sebagai catatan peristiwa, akuntansi sebagai realitas ekonomi, akuntansi sebagai sistem informasi, akuntansi sebagai komoditas, dan akhirnya akuntansi sebagai sebuah idiologi.

Dalam artikel ini, penulis tidak akan membahas perbedaan tersebut, namun akan lebih fokus pada mengkomparasikan semuanya untuk mencari kesatuan makna, kegunaan dan tujuan dari akuntansi itu sendiri dengan pendekatan sejarah perkembangan dan makna akuntansi dalam Islam.

\footnotetext{
${ }^{1}$ M. Ismail Yusanto, Pengantar Ekonomi Islam, (Bogor: Al-Azhar Press, 2009), h. 69.
} 


\section{Terminologi Akuntansi}

Secara terminologis, akuntansi berasal dari kata accounting yang artinya menghitung atau mempertanggungjawabkan. Akuntansi digunakan di hampir seluruh kegiatan bisnis di seluruh dunia untuk mengambil keputusan sehingga disebut sebagai bahasa bisnis.

Dalam bahasa Arab, akuntansi berarti al-muhâsabah, dari akar kata hâsaba, yuhâsibu, muhâsabatan, yang artinya penghitungan, akunting atau pertanggungjawaban. Akar kata ini dalam Alquran banyak sekali digunakan.

Kata "al-muhâsabah" dalam Alquran, terdapat dalam banyak ayat. Sebagai Muslim, Alquran dan Hadis adalah kitab undang-undang yang kita jadikan sebagai referensi bagi setiap persoalan dan aktivitas dalam kehidupan kita. Kalau kita hendak mencari kata "akuntansi" dalam bahasa populer dalam dunia bisnis saat ini, secara apada adanya, maka itu tidak ada dalam Alquran. Namun secara makna dasar, pemahaman, substansi, dan tujuannya, maka Alquran sudah mendahului para pakar akuntansi, jauh 1400 tahun yang lalu. Sebelum orang mengenal istilah matematika dan akuntansi.

Akar kata hâsaba, yuhâsibu, muhâsabatan, banyak sekali disebutkan dalam Alquran, seperti di dalam surah (Q.s. al-Baqarah [2]: 284), (Q.s. al-An'âm [6]: 62), (Q.s. al-Anbiyâ' [21]: 47), (Q.s. al-Thalâq [65]: 8) dan (Q.s. al-Insyiqâq [84]: 8). Cobalah kita amati firman Allah Swt. berikut:

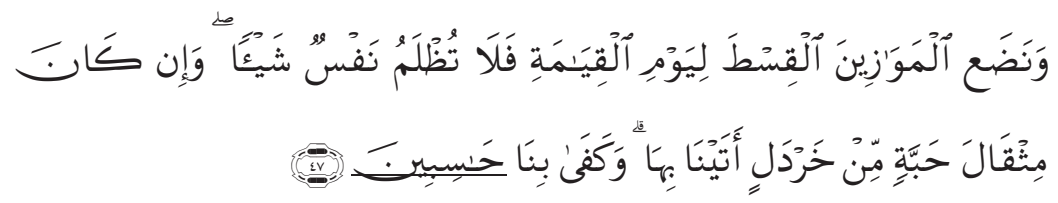

Kami akan memasang timbangan yang tepat pada hari kiamat, maka tidaklah dirugikan seseorang barang sedikitpun. Dan jika (amalan itu) hanya seberat biji sawipun pasti kami mendatangkan (pahala)nya. Dan cukuplah Kami sebagai Pembuat perhitungan". (Q.s. al-Anbiyâ' [21 ]: 47)

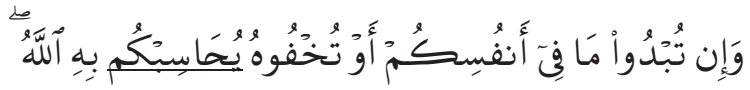

Dan jika kamu melahirkan apa yang ada di dalam hatimu atau kamu menyembunyikannya, niscaya Allah akan membuat perhitungan dengan kamu tentang perbuatanmu itu. (Q.s. al-Baqarah [2]: 284) 
Ayat-ayat di atas, menegaskan bahwa Allah akan menuntut pertanggungjawaban manusia atas apa yang ia kerjakan di dunia ini. Semua usaha, aktivitas yang kita lakukan akan dihitung semuanya oleh Allah Swt. Bukankah dengan demikian, ayat-ayat tersebut memotivasi kita untuk membiasakan diri dengan menghitung laba-rugi yang akan kita peroleh di kehidupan ini.

Dalam Alquran kata hisâb selalu dikaitkan dengan untung/laba-rugi. Dan ini adalah hakekat dari fungsi akuntansi yang memperhitungkan laba-rugi dalam aktivitas berbisnis. Baik bisnis di dunia dengan manusia atau bisnis akhirat dengan Allah. Hal ini karena laba itu $(+)=$ pahala, atau debit dan rugi $(-)=$ dosa atau kredit. Manusia dalam kehidupan dunia ini sedang mempersiapkan laporan laba-rugi tersebut. Demikian halnya Ilmu akuntansi dibuat dalam rangka untuk membuat laporan keuangan atau data keuangan terkait laba-rugi dan debitkredit.

Manusia dalam kehidupan dunia ini adalah bekerja untuk mencari keuntungan atau falah dalam kehidupan dunia dan ahiratnya. Dan setiap perbuatannya dicatat dan dihitung dalam buku debit dan kredit, oleh Malaikat Raqib dan Atid. Dan bahkan dalam hal ini pembukuannya dilakukan secara terpisah, antara debit dan kredit.

Ayat-ayat ini memotivasi kita untuk menjadi akuntan sejati. Yang selalu mengevaluasi diri sudah berapa banyak keuntungan yang kita raih dan seberapa banyak kerugian yang kita alami. Sebelum kerugian itu benar-benar diraih dalam kehidupan kedua kelak.

Dalam prespektif Hadis, Rasulullah Saw. juga menegaskan:

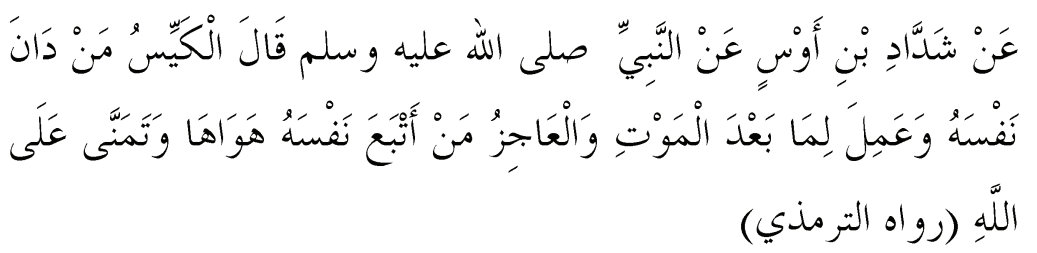

Dari Syaddâd ibn Aws, dari Nabi Saw. bersabda, "Orang yang paling pandai ialah orang yang melakukan perhitungan terhadap dirinya sendiri dan beramal untuk bekal sesudah mati orang yang lemah adalah orang yang mengikuti nawa nafsunya dan berangan-angan (anugerah) Allah." (H.r. alTirmidzî)

Demikian juga para sahabat, 'Umar ibn al-Khaththâb berkata: 


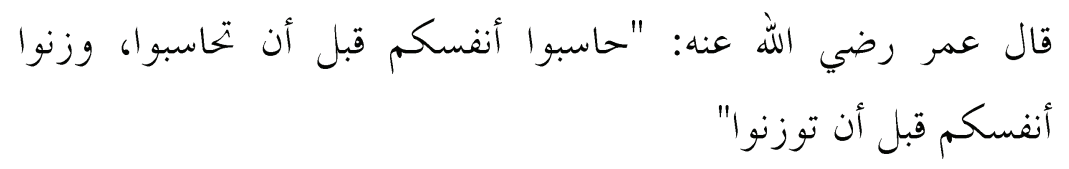

'Umar R.a. berkata, "Hisablah diri kalian sendiri sebelum dihisab, dan timbanglah amal perbuatan kalian sebelum ditimbang".

\section{Sejarah Akuntansi}

Akuntansi konvensional telah dikenal sejak manusia mengenal angka, yaitu sejak zaman Firaun di Mesir antara tahun 3000-1000 SM. Juga ada sejak zaman raja Hammurabi di Babilonia 2500-500 SM. Yang kemudian dikenal dengan perjanjian Hammurabi. Pada waktu itu masyarakat Mesir dan Babilonia telah mengenal adanya ilmu manajemen. Sebagaimana saat itu Firaun telah menerapkan ilmu manajemen dalam pembangunan Piramida².

Artikel ini akan mencoba menelusuri jejak-jejak sejarah akuntansi dalam Islam. Yang akar sejarahnya dimulai dari zaman Rasulullah sebagai pembawa risalah Islam. Pada masa awal Islam, akuntansi telah dikenal sejak zaman Rasulullah, yang secara umum termuat dalam beberapa surah (Q.s. al-Baqarah [2]: 284), (Q.s. al-An'âm [6]: 62), (Q.s. al-Anbiyâ' [21]: 47), (Q.s. al-Thalâq [65] :8) dan (Q.s. al-Insyiqâq [84]: 8), dan secara khusus termuat dalam surat al-Baqarah [2] ayat 282:

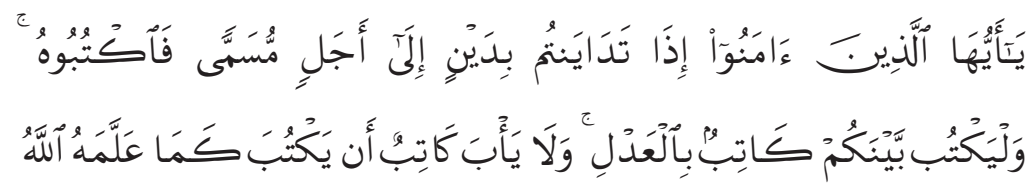

Hai orang-orang yang beriman, apabila kamu bermuamalah tidak secara tunai untuk waktu yang ditentukan, hendaklah kamu menuliskannya. Dan hendaklah seorang penulis di antara kamu menuliskannya dengan benar. Dan janganlah penulis enggan menuliskannya sebagaimana Allah telah mengajarkannya. (Q.s. al-Baqarah [2]:282)

Ayat di atas mengungkapkan indikasi akuntansi yang meliputi: utang dan piutang, jatuh tempo hutang, penulis hutang, keharusan berbuat keadilan dalam

2 Sofyan Syafri Harahap, Akuntansi Syariah, h. 79. 
penulisan, menuliskan perjanjian secara jelas, dua orang saksi, dan tujuan pencatatan ${ }^{3}$.

Sebagai kitab suci umat Islam, Alquran menganggap akuntansi sebagai suatu masalah yang penting. Dalam banyak ayat di atas banyak disinggung tentang al-hisâb, dan secara khusus diturunkan ayat terpanjang, yakni surah alBaqarah [2] ayat 282 yang menjelaskan fungsi-fungsi pencatatan transaksi, dasardasarnya, dan manfaat-manfaatnya

Dengan demikian, dapat kita saksikan dari sejarah, bahwa Islam lebih dahulu mengenal sistem akuntansi, karena Alquran telah diturunkan pada tahun $610 \mathrm{M}$, yakni 800 tahun lebih dahulu dari Luca Pacioli yang menerbitkan bukunya pada tahun 1494.

Dalam sejarah, Rasulullah Saw. sendiri pada masa hidupnya juga telah mendidik secara khusus beberapa sahabat untuk menangani profesi akuntan dengan sebutan "hafazhah al-amwâl" (pengawas keuangan)4 . Juga telah memerintahkan 42 orang sahabat yang berkompeten di bidangnya masing-masing dan digaji untuk mengurusi rumah zakat (bayt al-mâl).

Dengan demikian jelas pula begitu besarnya perhatian Islam terhadap akuntansi dalam perekonomian Islam bahkan telah diterapkan pula beberapa undang-undang akuntansi yang telah ada seperti undang-undang akuntansi untuk perorangan, perserikatan (syarîkah) atau perusahaan, akuntansi wakaf, hakhak pelarangan pengunaan harta (hijir), dan angaran negara. Maka dengan masa waktu semenjak tahun pertama hijriah sampai 23 hijriah, Rasulullah Saw. telah membangun pondasi akuntansi Islam detail yang di belakang hari akan diteruskan oleh sahabat-sahabat beliau, sebagai khalifah penerus jejak langkahnya ${ }^{5}$.

Sepeninggal Rasululullah Saw. pada tahun 632 M diangkatlah Abû Bakr alShiddîq sebagai khalifah pertama umat Islam. Abû Bakr memerintah selama dua tahun yaitu semenjak tahun 632-634 M. Selama sekitar 27 bulan memimpin Abû Bakr telah banyak menangani segenap kasus dan persoalan, di antaranya kasus orang-orang yang menolak untuk membayar zakat kepada negara. Pada masa Rasulullah, pendapatan bayt al-mâl (selain hewan) disimpan di Mesjid Nabawi, tapi pada saat itu tidak ada uang tunai yang tersisa. Berapapun uang yang masuk, langsung diditribusikan pada saat itu juga termasuk ketika bayt al-mâl menerima uang sebesar 80.000 dirham dari Bahrain.

\footnotetext{
${ }^{3}$ Samer Kantakji, The Role of Islamic Civilization in Developing Accounting Thought, h. 2.

${ }^{4}$ http://ilhamqmoehiddin.wordpress.com/2010/04/02/akuntansi-dalam-Islam

${ }^{5}$ Jaharuddin, "Akuntansi Islam dalam Lintasan Sejarah", dalam http://jaharuddin.blogspot.
} com. 
Abû Bakr meninggal dunia, digantikan oleh khalifah 'Umar ibn al-Khaththâb. Beliau memerintah kaum muslimin selama 10 tahun (13-23 H/ 634-644 M), selama masa pemerintahan 'Umar banyak sekali perkembangan ekonomi yang dijumpai dan dirasakan umat Islam. 'Umar banyak membuat kebijakan-kebijakan di bidang ekonomi. Karena perluasaan daerah terjadi dengan cepat, maka Khalifah segera mengatur adiministrasi negara dengan mengacu pada administrasi yang sudah berkembang terutama di Persia, yaitu dengan membagi pemerintahan menjadi delapan wilayah provinsi: Mekkah, Madinah, Syria, Jazirah, Basrah, Kufah, Palestina, dan Mesir.

Di masa zaman 'Umar ibn al-Khaththâb, telah membuat anggaran pendapatan negara, yang di zaman ini dikenal dengan APBN. 'Umar ibn al-Khaththâb membaginya menjadi empat bagian, yaitu: Bagian pertama, khusus untuk pengeluaran harta zakat, yaitu untuk kaum fakir, miskin, orang yang menangani zakat, orang yang terpikat oleh Islam, budak, orang yang terjerat hutang, sbilillah dan Ibnu sabil. Bagian kedua, khusus untuk pengeluaran dari 1/5 harta rampasan, yaitu untuk Allah Swt. Bagian ketiga, khusus untuk pengeluaran harta yang diserahkan kepada bayt al-mâl berupa barang temuan dan peningalan yang tidak ada ahli warisnya, maka sumber pemasukan ini digunakan untuk membe-rikan infak kepada kaum fakir. Bagian keempat, husus untuk pembiayaan ke-maslahatan umum. Ini dibiayai dari sumber pemasukan jizyah, kharaj, dan 'usyur.

Apa yang telah dirintis oleh 'Umar dilanjutkan oleh 'Utsmân ibn 'Affân dan 'Alî ibn Abî Thâlib R.a. Khalifah 'Alî dalam melaksanakan tugasnya mempunyai konsep yang matang dalam pemerintahan, dia mengangkat bendahara negara, dan setiap hari Kamis mampu mendistribusikan seluruh pendapatan yang ada di bayt al-mâl di Madinah, Basrah, dan Kufah dengan semua perhitungan yang diselesaikan pada hari itu juga dan perhitungan baru dimulai sabtu berikutnya ${ }^{7}$.

Pada masa al-Khulafâ' al-Râsyidin telah terdapat undang-undang akuntansi yang diterapkan untuk perorangan, perserikatan (syarîkah) atau perusahaan, akuntansi wakaf, hak-hak pelarangan penggunaan harta (hijr), dan anggaran negara. Di era khalifah setelah para sahabat, reliabilitas laporan keuangan pemerintahan dikembangkan oleh 'Umar ibn 'Abd al-'Azîz (681-720M) dengan kewajiban mengeluarkan bukti pemerimaan uang. Al-Walîd ibn 'Abd al-Mâlik (705 \pm 715 M) mengenalkan catatan dan register yang terjilid evolusi perkembangan pengelolaan buku akuntansi mencapai tingkat tertinggi pada masa kekuasaan dinasti 'Abbâsiyah.

\footnotetext{
6 Jahruddin, “Akuntansi Islam dalam Lintasan Sejarah”, http://jaharuddin.blogspot.com

7 Jahruddin, "Akuntansi Islam dalam Lintasan Sejarah".
} 
Pada masa itu, akuntansi telah diklasifikasikan pada beberapa spesialisasi seperti akuntansi peternakan, akuntansi pertanian, akuntansi bendahara, akuntansi konstruksi, akuntansi mata uang, dan pemeriksaan buku/auditing.

Sistem pembukuan menggunakan model buku besar, meliputi: (1) Jarîdah al-Kharâj (menyerupai receivable subsidiary ledger), menunjukkan utang individu atas zakat tanah, hasil pertanian, serta utang hewan ternak dan cicilan utang individu dicatat di satu kolom dan cicilan pembayaran di kolom lain. (2) Jarîdah al-Nafaqât (jurnal pengeluaran). (3) Jarîdah al-Mâl (jurnal dana), mencatat penerimaan dan pengeluaran dan zakat. (4) Jarîdah al-Musadarîn, mencatat penerimaan denda/sita dari individu yang tidak sesuai syariah, termasuk korupsi.

Akuntansi terus berkembang sejak ditemukannya angka oleh pakar matematika Muslim, al-Khawarizmi (Algoarism), pada awal abad IX M (780-850), penemu angka nol. Dan penulis buku, al-Mukhtashar fî Hisâb al-Jabar qa alMuqabala (Liber al-Gebras et Almucabola), yang mendapat julukan "Bapak Matematika"

Berikutnya muncul pada abad XV15, di Italia akuntansi dipopulerkan oleh Luca Pacioli, seorang Pendeta, yang menulis buku "Summa de Arithmatica Geometria et Propotionalita" dengan memuat satu bab mengenai "Double Entry Accounting Sistem". Munculnya Luka Pacioli di Eropa dengan menawarkan teori Double Entry Accounting merupakan hal baru bagi mereka, sehingga mereka menjadikannya sebagai referensi utama dalam akuntansi. Namun hal ini tidak fair, karena jauh sebelum Pacioli telah ada buku yang mengupas tentang teori tersebut. Banyak referensi mengatakan bahwa dia bukanlah penemu teori Double Entry Accounting Sistem.

\section{Akuntansi dalam Islam}

Klaim kemunculan ilmu akuntansi dari Italia oleh Luka Pacilo tidak diterima oleh cendekiawan Muslim. Karena sumber yang lebih valid menyatakan bahwa seorang tokoh Muslim bernama 'Abd Allâh al-Mazindâranî telah mendahului Luca Pacioli dalam bidang Akuntansi. Melalui bukunya, Risâlah al-Falaqiyyah Kitab al-Siqayah, pada tahun 1363 al-Mazindâranî telah membuat rumusan mengenai akuntansi. Dan Pacioli hanyalah seorang penukil dari informasi akuntansi yang sudah beredar saat itu ${ }^{8}$. Atau dia hanyalah mendeskripsikan secara sederhana metode yang digunakan oleh para pedagang di Venesia selama jaman Renaisance Italia.

\footnotetext{
${ }^{8}$ http://telagaalkautsar.multiply.com/journal/item/87/Kilas_Balik_Akuntansi_Islam_dan_Tantan gannnya
} 
Jadi sudah sepantasnya jika teknik tata buku berpasangan yang diklaim sebagai penemuannya digugat kebenarannya oleh para ilmuan, karena Luca Pacioli bukan pencipta atau perumus sistem tersebut ${ }^{9}$. Bahkan, Littlelon dan Yame (1978) menduga kalau sistem tata buku berpasangan ini berasal dari Spanyol dengan alasan bahwa kebudayaan dan teknologi Spanyol pada abad pertengahan tersebut jauh lebih maju dan unggul dibandingkan dengan peradaban Eropa, dan pada saat itu Spanyol adalah negara Muslim yang menjadi pusat kebudayaan dan teknologi Eropa.

Artinya, proses penumbuhan akuntansi di dunia Islam telah digunakan sekitar 745 tahun sebelum kemunculan buku Pacioly yang berjudul, Summa De Arithmetica, Geometry, proportion. Kemudian barulah akuntansi Islam menemukan puncak kegemilangannnya di tahun 765 H/1363 M dengan sebuah manuskrip yang disusun oleh 'Abd Allâh ibn Muhammad ibn Kayah al-Mazindâranî, bertajuk Risâlah Falaqiyyah Kitâb al-Siyâqah. Walaupun sebelum al-Mazindâranî menyusun manuskripnya tersebut. Penulis Muslim lainnya yang juga telah menyusun sebuah karya tentang perkembangan akuntansi dan penggunaaanya dalam masyarakat Islam juga telah dimulai oleh al-Nuwairî (734H/1336M) dan Ibn Khaldûn (167H/784M).

Di sinilah perlunya pemurnian informasi secara fair dan jujur, yaitu pada saat mata dunia tertutup oleh segenap keangkuhan pada karya gemilang yang pernah direntas oleh putra-putri Islam terbaik sepanjang masa. Pada saat jejakjejak ingatan kolektif masyarakat terkaburkan oleh sikap kesengajaan untuk menghilangkan kegemilangan yang pernah direntas oleh tangan-tangan insan berdedikasi dan berkeimanan.

Sebagaimana pemaparan pada paragrap sebelumnya, jauh sebelum pendeta Kristen pada tahun 1494 M yang bernama Lucas Pacioli dalam jangka perbedaan waktu Selama 131 tahun, tahun 1363 M al-Mazindâranî telah merentas pembukuan dua belas kolom atau kolom tunggal, dan disempurnakan olehnya untuk selanjutnya dapat diaplikasikan dalam sistem akuntansi yang tengah popular saat itu tahun 765 H/1363 M: (1) akuntansi bangunan, (2) akuntasi pertanian, (3) akuntansi pergudangan, (4) akuntansi pemuatan uang, (5) akuntasi pemeliharaan binatang.

Bahkan di antara yang sangat unik dalam pencatatan pembukuan pada masa tersebut dan juga merupakan pembeda antara akuntansi yang murni syariah dengan konvensional adalah sebagai berikut: Pertama, sebelum me-

\footnotetext{
${ }^{9}$ Iwan Triyuwono, Akuntansi Syariah, (Jakarta: PT. RajaGrafindo Persada), h. 21.
} 
nyiapkan laporan atau dimuat di buku-buku Akuntansi harus dimulai dengan basmallah. Hal inilah yang juga disebutkn oleh Lucas Pacioli 131 tahun kemudian $^{10}$.

Kedua, laporan keuangan dibuat berdasarkan fakta buku akuntansi yang digunakan, di antara laporan keuangan yang pernah dibuat di Negara Islam yang terkenal adalah al-Khitâmah dan al-Khitamah al-Jâmi'ah. Al-Khitâmah merupakan sebuah laporan keuangan tiap akhr bulan dan juga memuat pemasukan serta pengeluaran sesuai kelompok jenisnya sedangkan al-Khitâmaah al-Jâmi'ah laporan keuangan yang ditujukan untuk orang yang lebih tinggi derajatnya untuk kemudian diberi persetujuan laporan keuangan yang persetujuanya diberi nama al-Muwâfaqah, namun apabila ia tak disetujui maka ia dinamakan Muhâsabah karena adanya perbedaan pada data-data yang dimuat dalam laporan keuangan.

Ketiga, ketika melakukan transaksi jual beli, tanda terima diberikan kepada pembeli atau disebut juga dengan Thiraz sedangkan copiannya atau salinan disebut sebagai syahîd yang kemudian disimpan oleh Akuntan untuk kemudian dipertanggungjawabkan dan disetujui oleh pimpinan kantor, menteri, atau sultan dan apabila transaksi perdagangan terjadi di luar kota salinan syahid tersebut dikirim ke ibukota wilayah Islam untuk kemudian diberikan persetujuan oleh Sultan dan disimpan sebagai dasar pembukuan dasar kantor pusat.

Keempat, pada akhir tahun buku, seorang akuntan harus mengirimkan laporan keuangan dalam setahun dan secara rinci. Kelima, harus mengelompokkan transaksi-transaksi keuangan dan mencatatnya sesuai dengan karakternya dalam kelompok-kelompok yang sejenis ${ }^{11}$.

Dari kenyataan tersebut terbukti bahwa peradaban Barat tidak jujur dalam ilmu pengetahuan, mereka hanya mengakui apa yang mereka pandang berasal dari mereka, dan hasil penemuan mereka. Barat tidak mau mengakui karya orang Islam, karena mereka menganggap Muslim itu sebagai musuh. Menggunakan pemikiran dan karya musuh adalah kebodohan dan kekalahan bagi mereka. Oleh karena itu banyak karya-karya orang Islam yang diterjemah dalam bahasa Barat, namun mereka tidak menyebutkan pengarangnya, dan itu diakui sebagai karya mereka. Beberapa ilmuwan Muslim yang berhasil menghasilkan karya fenomenal pada teori ekonomi di antaranya adalah Ibn Taymiyyah, Ibn Rusyd, Ibn Khaldûn, al-Ghazâlî, dan masih banyak lagi.

\footnotetext{
${ }^{10}$ Johnson, 1963, h. 28.
}

${ }^{11}$ http://telagaalkautsar.multiply.com/journal/item/87/Kilas_Balik_Akuntansi_Islam_dan_Tanta ngannya.http://andra.web.id/2007/09/24/bapak-akuntansi-dunia. 
Banyak karya yang dihasilkan oleh para ilmuwan Muslim tersebut terhadap perkembangan ilmu ekonomi. Namun hal yang menyedihkan justru teori-teori mereka diklaim berasal dari Barat, padahal kalau kita kaji teori ekonomi yang signifikan pada dunia Barat, pertama kali dihasilkan oleh seorang profesor dari University of Glasgow yang bernama Adam Smith pada bukunya, An Inquiry Into The Nature and Cause Of The Wealth of Nations. Buku tersebut dihasilkan pada abad XVIII, yang bahkan isinya banyak terdapat kemiripan dengan buku Muqaddimah,, karya Ibn Khaldûn, yang dihasilkan beberapa abad sebelumnya.

Tokoh selanjutnya adalah al-Ghazâlî yang menyatakan bahwa kebutuhan hidup manusia itu terdiri atas tiga: kebutuhan primer (dharrûriyyah), sekunder (hâjiyyah), dan kebutuhan mewah (tahsîniyyah). Teori hierarki kebutuhan ini kemudian 'diambil' oleh William Nassau Senior yang menyatakan bahwa kebutuhan manusia itu terdiri atas kebutuhan dasar (necessity), sekunder (decency), dan kebutuhan tertier (luxury) ${ }^{12}$.

Kontribusi besar para ilmuwan ekonomi Islam inilah yang harus kita jadikan acuan untuk terus belajar dan menghasilkan karya-karya signifikan, baik dalam bidang ilmu ekonomi, maupun ilmu-ilmu lainnya.

Sistem etika Islam berbeda dari sistem etika sekuler dan dari ajaran moral yang diyakini oleh agama-agama lain. Sepanjang rentang sejarah peradaban, model-model sekuler ini mengasumsikan ajaran moral yang bersifat sementara dan berubah-ubah karena didasarkan pada nilai-nilai yang yang diyakini para pencetusnya, misalnya Epicurianisme atau ajaran tentang kebahagiaan demi kehagian semata. Model-model ini pada umumnya membangun sebuah sistem yang terpisah dari agama. Pada saat yang sama, ajaran moral yang diyakini oleh sejumlah agama lain seringkali terlampau menekankan nilai-nilai yang mengabaikan keadaan kita di dunia ini. Sebagai contoh, ajaran Kristen yang terlampau menekankan kedudukan biara telah mendorong pengikutnya untuk menyingkir dari hiruk-pikuk dan kesibukan kehidupan sehari-hari. ${ }^{13}$ Sebaliknya ajaran Islam yang menekankan hubungan antara manusia dengan Sang Pencipta dan sesama manusia itu sendiri.

Setiap sistem ekonomi pasti didasarkan atas idiologi yang memberikan landasan dan tujuanya, di satu pihak, dan aksioma-aksioma serta prinsip-prinsipnya, di lain pihak. Proses yang diikuti dengan seperangkat aksioma dan prinsip

12 Muhammad Imaduddin, dalam http://iqbal1.wordpress.com/2011/05/03/ekonomi-kontribusi-para-ilmuwan-muslim-terhadap-perkembangan-ilmu-ekonomi.

${ }^{13}$ Rafik Issa Beekun, Islamic Business Athics/ Etika bisnis Islam, penejemah: Muhammad (Yogyakarta: pustaka pelajar), h. 15. 
dimaksudkan untuk lebih mendekatkan tujuan sistem tersebut, merupakan landasan dari sistem tersebut yang bisa diuji. Setiap sistem ekonomi merupakan kerangka di mana suatu komunitas sosioekonomi dapat memanfaatkan sumbersumber alam dan manusiawi untuk kepentingan produksi dan mendistribusikan hasil-hasil produksi ini untuk kepentingan komsumsi. ${ }^{14}$

Ekonomi Islam diformasikan berdasarkan pandangan Islam tentang kehidupan. Sesunguhnya ekonomi Islam adalah bagian dari sistem Islam yang bersifat umum yang berdasarkan pada prinsip pertengahan dunia dan akhirat, individu, dan masyarakat. Dalam individu diseimbangkan antara jasmani dan rohani, antara akal dan hati, antara realita dan fakta. Dalam bidang ekonomi kita akan menemukan pelaksanaan prinsip keseimbangan pada semua bidang. Dia menyeimbangakan pelaksanaan prinsip keseimbangan pada semua bidang. Ia menyemimbangkan antara modal dan aktivitas, antara produksi dan komsumsi antara barang-barang yang diproduksi dengan yang lainnya. ${ }^{15}$

Akuntasi termasuk dalam kerangka ilmu sosial ekonomi, adapun eksistensi akuntasi dalam Islam dapat kita lihat dari berbagai bukti sejarah maupun dari pedoman suci Alquran. Alquran merupakan pegangan dan sumber hukum utama dari Islam. Oleh karenanya, wajib hukumnya bagi pemeluk agama Islam untuk menaati dan mengamalkan petunjuk dan perintahnya. Dalam Alquran surah al-Baqarah [2] ayat 282 yang merupakan ayat terpanjang dalam Alquran dapat kita baca sebagai berikut:

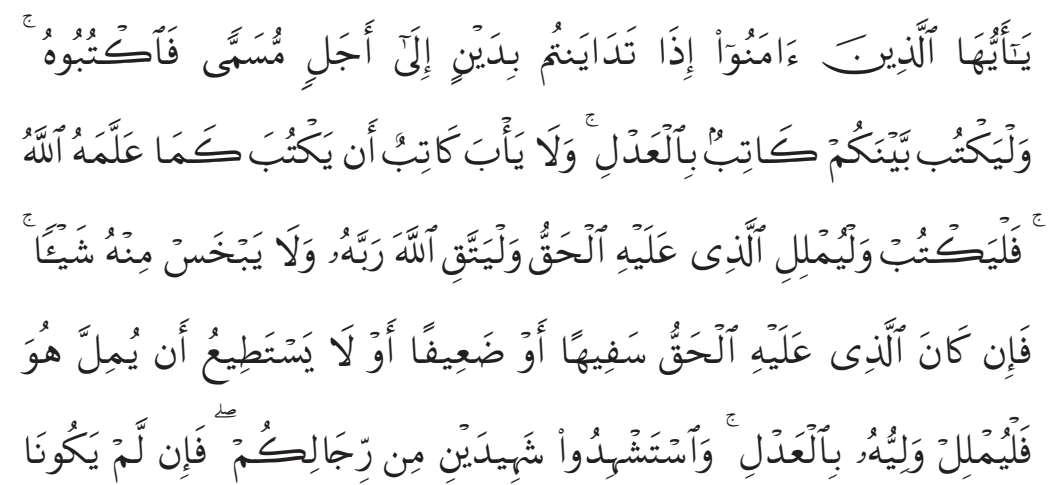

${ }^{14}$ Mustafa Edwin Nasution, Pengenalan Ekslusif Ekonomi Islam, (Jakarta: Kencana, 2010) ed,I., cet.3. h.32 .

15 Yusuf Qardhawi;Darul Qiyam wal Aklaq fil Iqstishodil Islami (Kairo; Maktabah Wabah)/Peran nilai dan moral dalam Perekonomian Islam/Didin Hafinuddin (Jakarta; Robbani Press. 1997 h. 86. 


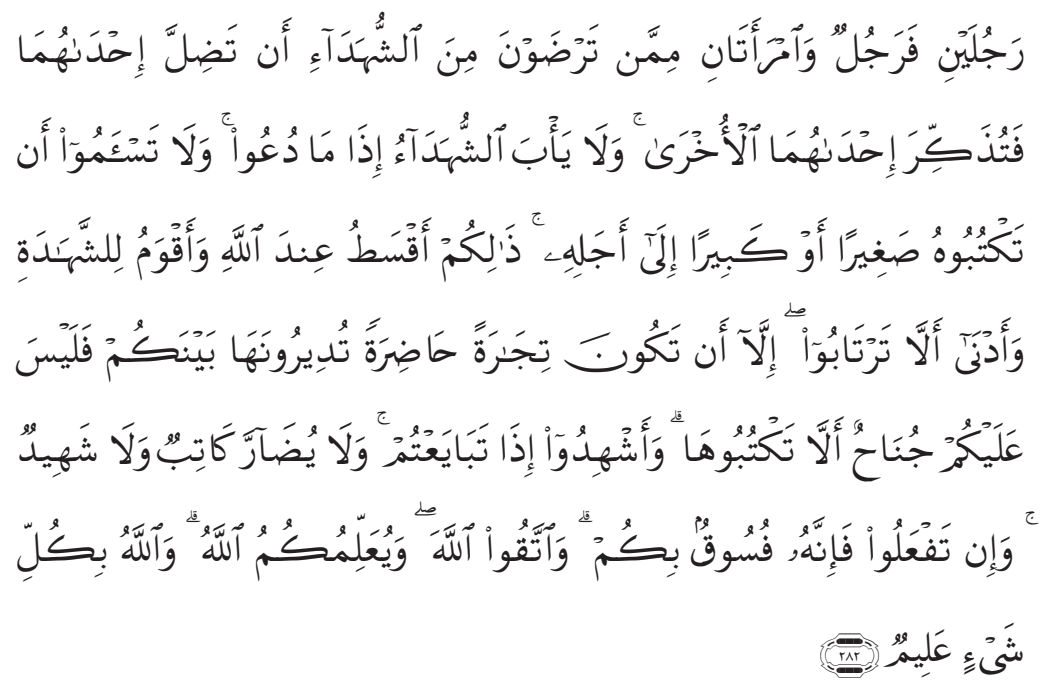

Hai orang-orang yang beriman, apabila kamu bermuamalah, ${ }^{16}$ tidak secara tunai untuk waktu yang ditentukan, hendaklah kamu menuliskannya. Dan hendaklah seorang penulis di antara kamu menuliskannya dengan benar. Dan janganlah penulis enggan menuliskannya sebagaimana Allah mengajarkannya, maka hendaklah ia menulis, dan hendaklah orang yang berutang itu mengimlakkan (apa yang akan ditulis itu), dan hendaklah ia bertakwa kepada Allah Tuhannya, dan janganlah ia mengurangi sedikitpun daripada utangnya. Jika yang berutang itu orang yang lemah akalnya atau lemah (keadaannya) atau dia sendiri tidak mampu mengimlakkan, maka hendaklah walinya mengimlakkan dengan jujur. Dan persaksikanlah dengan dua orang saksi dari orang-orang lelaki (di antaramu). Jika tak ada dua orang lelaki, maka (boleh) seorang lelaki dan dua orang perempuan dari saksi-saksi yang kamu ridai, supaya jika seorang lupa, maka yang seorang mengingatkannya. Janganlah saksisaksi itu enggan (memberi keterangan) apabila mereka dipanggil. Dan janganlah kamu jemu menulis utang itu, baik kecil maupun besar sampai batas waktu membayarnya. Yang demikian itu, lebih adil di sisi Allah dan lebih menguatkan persaksian dan lebih dekat kepada tidak (menimbulkan) keraguanmu. (Tulislah muamalahmu itu), kecuali jika muamalah itu perdagangan tunai yang kamu jalankan di antara kamu, maka tidak ada dosa bagi kamu, (jika) kamu tidak menulisnya. Dan persaksikanlah apabila kamu berjual beli, dan janganlah penulis dan saksi saling sulit

${ }^{16}$ Yang termasuk bermuamalah ialah, antara lain, seperti: berjual-beli, utang-piutang, atau sewa-menyewa, dan sebagainya. 
menyulitkan. Jika kamu lakukan (yang demikian), maka sesungguhnya hal itu adalah suatu kefasikan pada dirimu. Dan bertakwalah kepada Allah, Allah mengajarmu dan Allah Maha Mengetahui segala sesuatu. (Q.s. al-Baqarah [2]: 282)

Maksud dari bermuamalah dalam ayat ini adalah kegiatan jual-beli, berutang-piutang, sewa-menyewa, gadai, dan sebagainya.

Berutang-piutang tentu mempunyai pengertian yang luas dalam bisnis pendirian perusahaan pemilik modal menyakut utang-piutang antara dia dan manajemennya. Pengelolaan harta pemilik modal oleh manajemen merupakan hubungan utang-piutang (agency relationship). Hubungan transaksi dagang merupakan konteks utang-piutang, pinjaman ke lembaga keuangan mempunyai hubungan hutang-piutang. Oleh karena itu maka setiap lembaga perusahaan sarat dengan kegiatan muamalat sebagai mana dimaksud dalam ayat 282 di atas. Oleh karena itu dapat dipastikan bahwa pemiliharaan akuntasi wajib hukumnya dalam suatu perusahaan. ${ }^{17}$ Dalam Alquran surah al-Syu'arâ' [26]: 182-183 Allah berfirman:

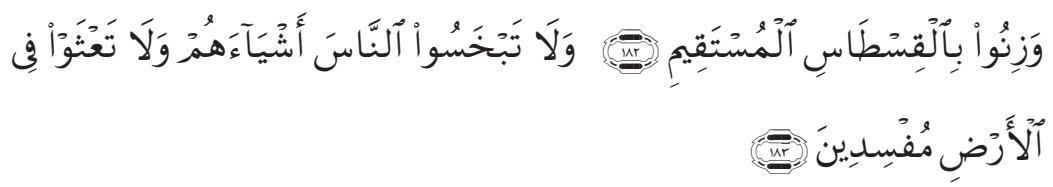

Dan timbanglah dengan timbangan yang lurus. Dan janganlah kamu merugikan manusia pada hak-haknya dan janganlah kamu merajalela di muka bumi dengan membuat kerusakan. (Q.s. al-Syu'ârâ [26]: 182-183)

Penggunaan sistem akuntasi jelas merupakan manifestasi dari pelaksanaan perintah ini. Karena sistem akuntansi dapat menjaga agar asset yang dikelola terjaga accountability-nya sehingga tidak ada yang dirugikan. Upaya untuk mencapai keadilan baik dalam pelaksanaan transaksi utang-piutang maupun dalam hubungan kerja sama antara pelbagai pihak seperti dalam persekutuan, musyârakah, dan mudhârabah, semuanya memerlukan sarana pencatatan yang tidak merugikan satu sama lainya sebagaimana spirit ayat di atas. Dalam kaidah fikih disebutkan untuk mencapai sesuatu yang diwajibkan maka sarana untuk mencapainya pun menjadi wajib. Oleh karena itu, dapat disebutkan bahwa me-

\footnotetext{
${ }^{17}$ Sofyan Syafri Harahap, Akuntansi Islam, (Jakarta: Bumi Aksara, 1999), h. 119.
} 
melihara pencatatan baik sebagai informasi, untuk menyasikan, untuk pertanggungjawaban, untuk pemeliharaan hak, atau untuk keadilan maka hukumnya termasuk menjadi wajib. ${ }^{18}$

\section{Penutup}

Bila dicermati konsep doeble entry dalam surah al-Baqarah [2] 282 dengan konsep keseimbangan, maka dalam neraca keseimbangan: (1) antara aktiva dan pasiva yang harus seimbang, (2) dalam aktiva (harta lancar dan harta tetap), (3) dalam pasiva ada dua pencatatan (utang dan modal).

Jika dianalisis dari penempatan surah itu dalam ayat kedua (doeble entry atau debet-kredit atau sebelah menyebelah) dapat menarik perhatian nama surah, al-Baqarah (sapi betina) yang merupakan nama komoditi perdagangan yang merupakan dagang akuntasi, dari segi angka ayatnya adalah 282 mengugah analisis seolah menggambarkan keseimbangan atau mîzân atau neraca (angka 8 diapit angka yang sama) hanya Tuhan mengetahui maksudnya.

Makna akuntansi dalam Alquran dan Hadis bersifat umum dan menyeluruh yang meliputi seluruh aktivitas manusia dalam kehidupan berinteraksi dan bertransaksinya dalam hubungannya dengan ibadah maupun transaksi sosial ekonomi. []

\section{Pustaka Acuan}

Beekun, Issa Rafik, Islamic Business Ethics/Etika bisnis Islam, penejemah Muhammad. Yogyakarta: Pustaka Pelajar.

Departemen Agama RI, Pedoman Zakat 9 Seri, Jakarta, Bagian Proyek Peningkatan Zakat dan Wakaf, 2002.

Muhammad, Akuntansi Lembaga Keuangan Syariah, Yogyakarta: Sekolah Tinggi Ilmu Syariah Yogyakarta, 1998.

Nasution, Edwin Mustafa, Pengenalan Ekslusif Ekonomi Islam, Jakarta: Kencana, 2010.

Qaradhawi, al-, Yûsuf, Dâr al-Qiyâm wa al-Akhlâq fi al-Iqstishâd al-Islâmî, alQâhirah: Maktabah Wahbah, Peran Nilai dan Moral dalam Perekonomian Islam, Didin Hafinuddin, Jakarta: Robbani Press, 1997.

Triyuwono, Iwan, "Akuntansi Syariah, Implementasi Nilai Keadilan dalam Format Metafora Amanah", Makalah Kuliah Umum Fakultas Syariah IAIN Walisongo Surakarta, 1997.

Triyuwono, Iwan, Akuntansi Syariah, Jakarta: PT. Graha Grafindo Persada, 2000.

\footnotetext{
${ }^{18}$ Sofyan Syafri Harahap, Akuntansi Islam, h. 122.
} 
, Perspektif, Metodologi, dan Teori Akuntansi Syariah, Jakarta: PT. RajaGrafindo Persada, 2010.

Wiyono, Slamet. Akuntansi Perbankan Syariah, Berdasar PSAK dan PAPSI, Jakarta: PT. Gramedia Widiasarana, 2005.

Yusanto, Ismail M., Pengantar Ekonomi Islam, Bogor: Al-Azhar Press, 2009. 